\title{
A MENTIRA TEM PE(R)NA CURTA?
}

\author{
Ricardo Tadeu Penitente Genelhú ${ }^{1}$
}

\section{RESUMO}

Este artigo discute a inconveniência da proposta de lei tendente a criminalizar a mentira veiculada em currículo porquanto isto representaria uma renormatização criminal de uma conduta já punida no Código Penal, além de remarcar a punição do excedente de mão de obra que visa, com eventual mendacidade, reequacionar sua vulnerabilidade laboral. Demonstra, por outro lado, que o poder punitivo, com a pena, não é a melhor saída para a consignação da confiança entre candidato ao emprego e empregador, pouco contribuindo para a empregabilidade. Por fim, revela a irrazoabilidade e a desproporção entre a criminalização e a sanção pretendidas e as já existentes na lege lata.

Palavras-chave: Legislação. Mentira. Curriculum vitae. Empregabilidade. Poder punitivo.

\begin{abstract}
This article discusess the inconvenience of the propose of Law that tends to criminalizate the false afirmation on curriculum because it would represent a criminal renormatization of a conduct already punished in Penal Code, further than remark the punishment of the surplus of labor that wants, eventually, restructure its labor vulnerability. Shows that, for the other side, the punitive power, with penal punishment, is not the Best way for consign the trust between the job candidate and the employer, contributing less for the employability. In the end, argues the unreasonableness and the disproportion between the criminalition and the sanction tended and those already existing laws.
\end{abstract}

Key words: Legislation. Lie. Curriculum vitae. Employability. Punitive Power.

Um projeto de lei de número 6.561, de 2009, do Deputado Federal CARLOS BEZERRA, do PMDB do Mato Grosso, prevê a criminalização da mentira ventilada em curriculum vitae, com a indivorciável consequência da cominação de pena privativa de liberdade para os mendaces sob o auspício de, com ela, arrefecer as informações inverídicas e exageradamente alegadas como perniciosas -, incrustadas naquele documento que, mesmo sendo particular, serviria - nesta dança das insuficientes cadeiras que é o mercado de trabalho -, de assento para a segurança das e confiança nas relações empregatícias, sobretudo naquele momento do seu descortino, qual sendo, a da opção pela contratação de um candidato em detrimento de outro.

A pretensão do referido parlamentar esquece, porém - se é que ela, ainda que involitivamente, não se sente atraída por seus encantos e dividendos políticos -, das funções latentes ou reais da pena privativa de liberdade que - mesmo com a advertência de ZAFFARONI, NILO, ALAGIA e SLOKAR de que "o poder estatal concede às suas instituições funções manifestas, que são expressas, declaradas e públicas. Trata-se de uma

\footnotetext{
${ }^{1}$ Mestre em Direito pela Universidade do Estado do Rio de Janeiro.
} 
necessidade republicana; um poder orientador que não expresse para que é exercido não pode submeter-se ao juízo de racionalidade. Porém, em geral, essa função manifesta não coincide por completo com o que a instituição realiza na sociedade, ou seja, com suas funções latentes ou reais. Tal disparidade deve ser sempre objeto de crítica institucional, porque é a única maneira de controlar a racionalidade do poder, pois, em caso contrário (se a discussão se mantiver ao mero nível das funções manifestas), o controle seria de pura racionalidade do discurso." ${ }^{2}$-, demonstram que esta, em verdade, nada mais faz que controlar o excedente de mão de obra ${ }^{3}$ sazonalmente inútil ao mercado de trabalho, porquanto ele pode, e reitero que apenas pode, voltar a ser útil após sua reciclagem no artefato industrial carcerário da domesticação para a aceitação dócil das condições empregatícias indignas a que estão sujeitos os assalariados brasileiros. ${ }^{4}$

Quer-me parecer, porém, que, assim como a mentira irá, equivocadamente, servir de gabarito para a medição da segurança ou insegurança do mercado de trabalho, manufaturando a proteção do mesmo via criminalização e penalização dos trabalhadores que, desesperados, socorrem-se de um dos poucos armamentos que lhes estão disponíveis, qual sendo, um farisaísmo inocente e movido pelo desespero, referido projeto de lei igualmente deveria receber, em contrapartida, uma pena, porquanto sua cogitatio legiferativa - desatenta à inflação legal -, acaso convertida em lei, também representa outra mentira, agravada, aqui, por uma latitude pública, i. e., a de estar contida em um "diploma legal penal", portanto, de consequências muito mais graves, pois neste está vazada a talvez segunda maior - a primeira está consagrada no artigo 59, do Código Penal, e revela que as funções manifestas da pena são a reprovação e a prevenção -, de todas as falácias penais consignadas expressamente, qual sendo, a de que a pena privativa de liberdade retribuirá o eventual mentiroso, e auxiliará a sociedade, leia-se, o mercado de trabalho capitalista, a prevenir-se contra o mesmo e contra os demais pretendentes de, respectivamente, novamente, ou, originalmente, mentir em seus currículos, e, assim, ter certeza de que, se há um inimigo, ele é inempregável.

\footnotetext{
${ }^{2}$ ZAFFARONI, Eugenio Raúl; BATISTA, Nilo; ALAGIA, Alejandro; SLOKAR, Alejandro. Direito Penal brasileiro: teoria geral do Direito Penal, v. I. Rio de Janeiro: Revan, 2003, p. 88.

${ }^{3}$ MELOSSI, Dario; PAVARINI, Massimo. Cárcere e fábrica: as origens do sistema penitenciário (séculos XVI - XIX). In coleção pensamento criminológico, n. 11. Rio de Janeiro: Revan/ICC, 2006, passim.

${ }^{4}$ Nesse sentido, envolvendo sobretudo a medicina, e não como coadjuvante, alcança COSTA, Jurandir Freire. Ordem médica e norma familiar. 5. ed. Rio de Janeiro: Graal, 2004, p. 52, o resultado de: "a proliferação e a liberação de uma mão de obra politicamente dócil para o livre jogo do mercado de trabalho."
} 
Ora, muita vez, a mentira é o único subterfúgio que o desempregado tem de tentar reequilibrar, conquanto sem muito sucesso, as forças mercadológicas que o esmagam, remanescendo punidos e mal pagos, ${ }^{5}$ ou melhor, impagos, porquanto desempregados.

Pensar em contrário significa retirar o criminalizável da lista de candidatos ao emprego livre para empregá-lo, via mão de obra braçal, na edificação do novo programa habitacional para os pobres financiado pelo governo mediante intervenção da CEF - Centro para os Escolhidos Fracassados. ${ }^{6}$

De sorte que, esta seria uma lógica contraditória onde se criminalizaria os incapacitados - ou melhor, convenientemente inservíveis sob o ângulo de visada do capital -, para o mercado de trabalho, inúteis por comporem o excedente de mão de obra, enquanto que, por outro lado, eles mesmos serviriam como força bruta na exploração carcerária do braço fungível, e sem direito a adicional por periculosidade, insalubridade e penosidade.

O projeto de lei, então, e aqui faço uma afirmação temperada com sal ático, parece encerrar o estilo do me dá cá aquela palha, quando despreza que a pena para quem mentir em seu currículo plagia o cão que rotaciona atrás da própria calda, visto que sancionará com a proscrição do mercado de trabalho aqueles sujeitos cuja desqualificação e incapacitação já os lançou no nariz-de-cera dos invisíveis sociais, etiquetados, ao nascer, com a chance quase indesviável de receber uma pena - e esse será seu pagamento -, única e exclusivamente, em razão desta sua condição.

Então, o projeto nada mais faz que enfatizar esse destino, autoconfirmando a profecia e impedindo os criminalizáveis de, ad instar do Barão de MUNCHHAUSEN, erigirem-se da lama alçando-se pelos próprios cabelos ${ }^{7}$ ou, quem sabe, peruca, porque, não devemos esquecer, seriam eles considerados, com a aprovação do projeto, também, mentirosos. Daqui a pouco, ser calvo - e aqui me perdoem o eufemismo voltado para o pouco de orgulho que me resta -, como eu, e usar peruca, mentindo ou ludibriando, também será crime ${ }^{8}$. Ou alguém duvida disto? A minha sorte é que eu não uso cabelos postiços.

Este é um dos grandes problemas encartados no poder punitivo e na sua essência, qual sendo, a pena.

\footnotetext{
${ }^{5}$ Essa é uma paródia à satírica obra de BATISTA, Nilo. Punidos e mal pagos: violência, justiça, segurança pública e direitos humanos no Brasil de hoje. Rio de Janeiro: Revan, 1990.

${ }^{6}$ Aqui me aproveitei da famosa imagem de LOÏC WACQUANT.

${ }^{7}$ RAsPE, Rudolf Erich; Bürger, Gottfried August. As aventuras do barão de Münchhausen. São Paulo: Círculo do Livro, sem data, p. 33.

${ }^{8}$ Ou melhor, criminalização.
} 
Acredita-se, ou não há interesse em desacreditar - servindo como testemunhas dessa cegueira as inegáveis subsidiariedade e fragmentariedade -, que o menu da pena e do poder punitivo conseguirá resolver o problema da criminalização e do criminalizado quando, em verdade, estes não representam um problema, senão, o efeito de um problema antecedente, é dizer, o da desestruturação familiar, da perplexidade do relativismo moral e cultural, do contraste econômico etc, ampliados pelo desmonte de um Estado providente em benefício de um Estado repressor que, à laia de resolvê-lo, nada mais faz que ratificá-lo ao etiquetar como criminosos aqueles que ele próprio desassistiu, ad instar do gerente do supermercado que, adquirindo mercadoria própria ao consumo, por negligência a expõe fora da sua prateleira adequada e, percebendo a chegada do seu vencimento, oferece-a a preço mais baixo que, não sendo aceito, mediante a comparação entre seus benefícios, prazo de validade e valor, jaz ali, passiva, até ser inutilizada.

Ontologicamente, a pena é a nota - que, na perfumaria penalística, vem acompanhada de um fixador indelével -, característica do direito penal (rectius: poder punitivo), embora tenha havido um inegável abuso do seu manejo até hoje.

E a abusão, desde o Código Penal de 1830, copiosamente até o Código Penal de 1940, sempre se pautou na promessa - incumprida, ou quando menos, improvada -, propagandeada como realizada, de que os sonegados efeitos deletérios da pena seriam compensados pela sua utilidade retributiva e preventiva incluída na eleição do coletivo em detrimento do individual (retribuição e prevenção geral), ou deste em razão dele mesmo (prevenção especial).

Em todo caso, a pena nada mais é que uma reprodução metafórica de poder onde quem domina o discurso expõe aos e convence os jurisdicionados de que o crime é um mal (retribuição) e um perigo (prevenção) para, mais tarde, mas não com demora, vender a preço baixo o serviço de controle do mesmo mediante o uso da pena, panacéia para todos os crimes.

Neste contexto, a pena assume uma função emblemática de mitificar, na pele, na carne, no osso e na mente do escolhido, a redenção messiânica já realizada a favor de todos há dois mil anos.

Sob estes auspícios, a pena percorreu em terras brasileiras mais de cinco séculos de invenção e reinvenção da realidade que enxerga o homem como uma possível reificação e como um instrumento de exemplo.

O problema é que, dependendo do papel que lhe outorgam, esta mesma personagem assume uma condição diferente, ou seja, quando recebe uma pena, afirma o poder punitivo que ela é igual a todas as demais pessoas, mesmo porque - seguindo, a contragosto, esta lógica contraditória -, o contrário revelaria que os demais membros da sociedade deveriam se 
pautar, espelhar-se em alguém diferente, inferior ou pior. Por outro lado, quando ela é etiquetada como criminosa, impõe-se-lhe o invólucro de diferente da maioria, ou melhor, uma desigual.

Só por isto as teorias da pena se contradizem, falecendo ao poder punitivo uma coerência interna, porquanto uma só pessoa, ao mesmo tempo, é reputada inferior quando dizem que ela infringiu a lei penal, enquanto esta mesma pessoa é considerada igual para efeito de servir de modelo, estandardizado, para que outros não incorram no mesmo erro, quase como aquele "ser que não deve ser", noticiado por ZAFFARONI, BATISTA, ALAGIA e SLOKAR. ${ }^{9}$

Esse jogo de conveniência arbitrado pelo poder punitivo não segue uma lógica que não a da reprodução ideológica necessária na ocasião para, iludindo com uma manobra prestidigitadora muito bem ensaiada, atender aos reclamos da manutenção do discurso punitivista de oradores que insistem em reclamar um espaço assumido a duras penas - penas estas cumpridas por terceiros, obviamente -, cuja expansão territorial, via renormatização, sempre pode ser manejada ou com uma ação de esbulho - onde o criminalizado perde mais uma parte da sua liberdade -, ou com uma ação de turbação - em que o criminalizado e toda a sociedade são perturbados pelos constantes alarmes que o poder punitivo remotamente soa com o fim de, recriando e reinventando os anseios humanos, detonar estratégias de solução pré-fabricadas -, ou com uma ação de interdito proibitório - de petição inicial facilmente deferível nestes tempos de vigilantismo policial onde quase mais nada é permitido e quase tudo é proibido, em flagrante administrativização do direito penal. ${ }^{10}$

Ocorre que, quanto às teorias da pena quer-me parecer que suas falácias, infelizmente, não têm perna curta, espraiando-se no tempo e no espaço, alcançando, via mass media e agências de repetição ${ }^{11}$, um número cada vez maior de pessoas que, convencidas e iludidas pela eloquência daquelas, concordam que a sanção penal funciona, seja para retribuir a criminalização, seja para preveni-la quando, em verdade, sabe-se que a criminalização nada mais é que um apontar de dedo - quase nunca higienizado -, que indica quem, e quando esse alguém deverá ser rotulado como um criminoso e por qual motivo, ou melhor, desculpa ou, ainda melhor, mentira!

\footnotetext{
${ }^{9}$ Zaffaroni, Eugenio Raúl; Batista, Nilo; Alagia, Alejandro; SloKar, Alejandro. Direito..., pp. 652 e seguintes.

${ }^{10}$ Refiro-me à regra voltada para a Administração em que só não está proibido o que está expressamente autorizado.

${ }^{11}$ Refiro-me, aqui, a todas as agências que se furtam de assumir uma posição crítica, e nada construtiva, do poder punitivo.
} 
Mentira esta que, sem concessão, tem caído no asseguramento, geralmente mediante proscrição social, contra aquele que se diz haver dissentido sem justificativa da ordenação advinda de quem domina o discurso, com a consequente estabilização da sociedade.

Como rascunhei acima, antes mesmo de ser rotulado como criminoso, esse ser humano já ocupava, como interior biodegradável, embalagem reutilizável, futuramente, na esteira produtiva serial da indústria do encarceramento.

Ou seja, devido às suas condições ambientais, raciais, culturais, financeiras e genealógicas, já nasceu com a exclusiva função de prestar-se como cordeiro cuja imolação servirá de tributo a um deus - o poder punitivo -, que ameaça com a escatologia todos que o desafiam.

Mas, que malditas mentiras seriam estas?

Pois bem. Arrimando-se na última parte do artigo 59, do Código Penal, o poder punitivo afirma que pretende, com a pena, reprovar, é dizer, retribuir, e prevenir o mal ocasionado pelo criminoso, elegendo, com isto, as teorias que, colimando justificar sua mantença, ganharam a alcunha, total, de absoluta e relativas, respectivamente.

Ocorre que esta é uma pretensão inalcançável, além de ser inverídica, porquanto a função real da pena, e que, infelizmente, permanece escondida dos olhos da maioria, é controlar o excedente de mão de obra a favor do mercado capitalista/punitivo.

Mas, antes de demonstrar esta sua função, gostaria de descortinar as falsas funções manifestas ou irreais da pena. Se não, vejamos onde se encontram seus fingimentos.

Se retribuir significa devolver, compensar, não entendo possível continuar acreditando que a pena, por si só, terá o poder de restituir a vítima, ou outro legitimado, ao status quo ante, servindo como exemplo a não ressuscitação do atingido pelo homicídio, imediatamente quando do encarceramento do réu.

Em igual medida, não se pode afirmar que a retribuição apenativa tenha funcionado no caso do médico, cirurgião plástico, que, lesionando a face da sua esposa, e preso por este motivo, devolve-lhe, quando já em liberdade, a beleza original após intervenção cirúrgica estética que o mesmo realizara espontaneamente. Neste caso, podem ter operado questões de natureza vária, como arrependimento, confinado no campo da moral, expiação religiosa autoimpingida etc, incluída a própria pena. Acontece, porém, que a improbabilidade ${ }^{12}$ da atuação exclusiva desta, de per se, já é motivo suficiente para desacreditar a pena, de resultados sempre altamente drásticos, como instrumento de retribuição.

\footnotetext{
${ }^{12}$ No sentido de indemonstrabilidade, ou melhor, não demonstração.
} 
O engraçado - se já não fosse trágico -, é que, justamente nas criminalizações menos importantes para a demagogia legislativa, onde se encaixa a substituição da pena privativa de liberdade pela pena restritiva de direitos, e onde não se fala em empreendimento de violência e grave ameça, é que a retribuição pode realmente funcionar, como, por exemplo, na perda de bens e valores tanto como restituição do patrimônio da vítima, quanto como na perda de bens e valores, novamente - sob pena de referida modalidade servir de incentivo -, agora sim, como sanção.

Mas, é justamente nestes casos que ela é despicienda, porquanto o direito civil, ou o direito administrativo já possuem ferramental eficaz para resolver tais situações. Ineficaz ou improvável nas criminalizações mais graves e desnecessária nas menos graves, parece remanescer aí a inumação definitiva da retribuição como teoria que, malogradamente, tenta justificar a manutenção da pena.

Com efeito, a retribuição não passa de uma reincidência de poder que, pela técnica do reenvio, remete os dominados/desempregados ao pavilhão - auditivo -, onde o discurso dos dominantes/potenciais/empregadores está sendo veiculado mediante uma oratória que dispõe que a mentira noticiada desequilibraria a competição por emprego, merecendo, portanto, a proteção penal, única capaz de reequacionar (retribuição) a perda do emprego em razão daquela mentira.

Todavia, isto não passa de um engodo. Na verdade, com a desculpa da retribuição pela mentira, o poder punitivo visaria a se proteger contra aqueles que o desafiassem, proscrevendo-os do mercado de trabalho - porquanto sua vitória ameaçaria o poder dos dominantes ao reequilibrar as forças, rehomogeneizando-as -, pois seria neste que o homem adquiriria o status de igual aos demais - condição equivalente a daqueles que solicitam a atuação do poder punitivo visando proteção contra os alegados inferiores/desempregados -, estando, assim, capacitado a participar, politicamente - no sentido amplo desta palavra -, da composição, recomposição, ou afastamento deste ou daquele discurso interessante ou indiferente aos seus anseios.

Quem domina o discurso não pretende passar da condição de dominante a dominado. Daí, o mister de alijar o excedente de mão de obra indócil que, indetido naturalmente pela incapacidade e desqualificação, insiste em, mediante uma mentira curricular, inserir-se no mercado, reequilibrando as forças.

Por isso, não vejo problema, ao menos não um problema penal, em vazar uma mentira no curriculum vitae, pois, lembrando RUSCHE e KIRCHHEIMER, é impossível não concordar que "a taxa de criminalidade pode de fato ser influenciada somente se a sociedade 
está numa posição de oferecer a seus membros um certo grau de segurança e de garantir um nível de vida razoável. ...A futilidade da punição severa e o tratamento cruel podem ser testados mais de mil vezes, mas enquanto a sociedade não estiver apta a resolver seus problemas sociais, a repressão, o caminho aparentemente mais fácil, será sempre bem aceita."13

Por acréscimo, uma vez encarcerado, o mentiroso, docilizado pelo sistema, voltaria ao mercado aceitando suas condições subhumanas ou, não aceitando-a, receberia um recall para retornar para aquele e, assim, passar por um processo de reciclagem, colimando sua docilização, ou sua consideração como um produto descartável, restando neutralizado, dentro ou fora da prisão (prevenção especial negativa), para sempre.

Quanto à prevenção, o poder punitivo defende que, com a pena, ele pretende prevenir a sociedade contra potenciais criminosos ${ }^{14}$ (prevenção geral positiva) ou contra um criminoso $^{15}$ específico, o possível reincidente (prevenção geral negativa).

Entrementes, a pena sonega que seu uso preventivo está atrelado, exclusivamente, à defesa do próprio poder punitivo e da sua posição sobranceira de dominador de um discurso que admoesta (promete) que, sem ele, a sociedade desmoronaria.

É a profecia que se autorrealiza, vaticinando o poder punitivo que o crime é um mal insuportável para a sociedade que, diante disto, precisa convocar ele, poder punitivo, como único competente para debelá-lo, à semelhança daquela hipótese folclórica em que o veneno é vendido junto com o antídoto, ou daquela em que o borracheiro espalha pregos na rua da sua propaganda.

Requentando, nesta teoria do "faça o que o poder punitivo manda, mas não faça o que ele faz", o poder punitivo quer, nada mais, nada menos, que proteger a si mesmo contra pessoas que possam ameaçar sua dominação discursiva, no caso, os desempregados, pois, alcançando a empregabilidade, mediante a mentira, estes acessariam um locus que lhes poderia atingir uma capacidade de eloquência suficiente para, desadestrando-se, espraiar ou acentuar sua crítica contra aquele.

Então, com o uso da pena nunca houve a intenção de proteger a sociedade contra os criminalizados, senão, proteger o poder punitivo, mediante gatilhos semiautomáticos, contra ataques dirigidos, direta ou indiretamente, em desfavor da sua posição a cavaleiro dos

\footnotetext{
${ }^{13}$ RUSCHE, Georg; KIRCHHEIMER, Otto. Punição e estrutura social. In coleção pensamento criminológico, n. 3. 2. ed., Rio de Janeiro: Revan/ICC, 2004, p. 282.

${ }^{14}$ Ou melhor, criminalizáveis.

${ }^{15}$ Mais correto dizer, criminalizado.
} 
dominados. Assim, para evitar este xeque-mate, ele elimina do tabuleiro as peças que o ameaçam diretamente, ou mesmo indiretamente, como no caso em que alguém, passando da posição de desempregado a empregador - troca de papéis que me parece pouco provável -, ousa fazer ouvido de mercador irrelevando seu discurso controlador do excedente de mão de obra ao tentar se fichar mediante curricular (curriculum), embora vital (vitae), mentira, sem a qual só lhe restará submeter-se ao mais punitivo, cruel e arbitrário dos empregadores, o Estado-carcerário.

De sorte que, o fim irreversível da pena - sem direito a velório, a luto e a missa de sétimo dia -, como contrapartida a um pretenso mal causado não encontra subsídio somente nestes argumentos. É dizer, sem receio do enfadonho, o poder punitivo, escudado em um discurso verbal e imagético, tenta nos convencer que teria a pena o objetivo de proteger a sociedade contra prováveis criminosos, ou, ainda, protegê-la contra um provável reincidente, instrumentalizando-os em ambos os casos.

Esta história de que a pena serviria, teoricamente, para o reforço da norma (prevenção geral positiva) não passa daquela paródia funcional que revelei en passant acima, i. e., que mistifica que a norma penal, e sua sanção, a pena, autopropagandeadas pelo poder punitivo como necessárias, são também suficientes para proteger a sociedade contra os criminosos.

Acontece, porém, que, com o cometimento de um crime - destacada uma conduta com a etiqueta da criminalização -, referido discurso se fragiliza, enfraquecendo a confiança em um produto cujo marketing agora evidencia que prometeu mais do que o produto realmente continha. Com isso, o gatilho inflacionário legislativo imediatamente dispara, renormatizando ${ }^{16}$ aquele tipo, ou redimensionando sua aplicação mediante a imposição de pena sob a alcunha de reforçar a norma, funcionalizando normativamente a política criminal que, a partir de então, vê-se voltada a converter uma sociedade em instrumento a favor de outro instrumento - a pena, ou melhor, a posição sobranceira de dominador do discurso

\footnotetext{
${ }^{16}$ Sobre a renormatização, veja ZAFFARONI, Eugenio Raúl; BATISTA, Nilo; ALAGIA, Alejandro; SLOKAR, Alejandro. Direito..., pp. 53-54: "Mas quando as agências políticas - por qualquer motivo - não podem dispor de medidas que resolvam o conflito, elas se valem da renormatização da situação conflitiva: esta não se resolve, mas se renormatiza por meio da formalização de um ato programático declarativo de criminalização primária do comportamento de quem exerce aquele poder e, ao mesmo tempo, de um ato de vitimização primária, que reconheça o status de vítima ao subjugado. Deste modo são tranquilizadas as pessoas que reivindicam o reconhecimento de seus direitos lesionados em meio a essas situações conflitivas, cujos explicáveis impulsos vindicativos passam a ser canalizáveis para a realimentação do sistema penal, estimulando-se que a opinião pública se identifique com eles, e procurando que todos aqueles que suportam ofensas análogas se satisfaçam com o reconhecimento de seu novo status (vítimas). Desta maneira, a situação desnormatizada se renormatiza (sai do centro da atenção pública)."
} 
ocupada pelo poder punitivo -, como naqueles casos, aqui inservíveis, pois nada antropo(teleo)lógicos, em que o instrumento serve de instrumento para outro instrumento.

O desemprego por justa causa, advirta-se, parece estar batendo, também, à porta da prevenção geral negativa, de sorte que, a coação psicológica não pode, tampouco deve, continuar sendo usada como justificativa para a aplicação futura de uma pena que pretende ensinar para a liberdade, mediante a privação da liberdade ${ }^{17}$, aqueles que mentiram curricularmente, justamente porque não tiveram a liberdade de optar por agir diferentemente. É dizer, não tiverem a oportunidade de escolher uma profissão digna, um trabalho honesto, um empregador decente, pois tudo isto lhes foi furtado in fieri, desde quando nasceram mediante a contrafática alocação, randômica, em família, ambiente e estrato social desfavoráveis. Aqui, o poder punitivo, igualmente, não visa, com a pena, coagir terceiros, inclusive o mentiroso caso pretendesse ele reincidir. A renitência deste e o ânimo daqueles pretende ser desfeito pela intimidação, concordo, mas não com aquele objetivo, requentado, de proteger a sociedade, senão, de proteger, novamente, o poder punitivo contra aqueles que, com suas respectivas condutas, ameacem sua posição de dominador do discurso e controlador do mercado laboral.

Com a pretendida criminalização da mentira no estádio curricular, o poder punitivo deseja, mediante coação psicológica, impedir, ou, ao menos, diminuir as chances de perder o controle sobre os incapacitados que somente podem adentrar no mercado de trabalho quando os índices do termômetro punitivo demonstrarem que há um deficit de mão-de-obra fungível, cuja substituição precisa ser provida pelo estoque de invisíveis sociais ou de encarcerados, também invisíveis a terceiros.

Do contrário, poderia haver, além da perda de território discursivo dominial, um desequilíbrio do mercado de mão de obra - em razão do reequacionamento entre a oferta e a demanda, com provável elevação dos salários, ou mediante uma insatisfação na perda de empregos ao nível dos capacitados -, com a consequente perda de lucro do capitalista/empregador.

Então, não tenho certeza se é de todo inequívoco entender que o aumento do número de candidatos ao emprego diminuiria as faixas salariais, porquanto se deve lembrar que uma pequena quantidade de pessoas especializadas terá direito a um altíssimo salário, enquanto

\footnotetext{
17 Extraído de HASSEMER, Winfried. Introdução aos fundamentos do Direito Penal. Porto Alegre: SAFE, 2005, p. 378: “Educação para a liberdade através da privação da liberdade"” não é apenas o título bem elaborado de uma publicação, mas expressa o evidente paradoxo das modernas teorias da pena."
} 
que uma altíssima quantidade de pessoas incapacitadas e, portanto, consuntíveis, terá um salário achatadíssimo. Mas, não é só isso.

É dizer, não se deve esquecer que um aumento acima do vértice da Curva de Lafer, ou seja, um aumento excessivo da oferta de mão de obra em razão da demanda, ensejaria uma redução salarial drástica tal que daria azo a uma incapacidade do empregado de adquirir os produtos que ele mesmo fabrica, ${ }^{18}$ tal como aconteceu, mutatis mutandis, na abolição da escravatura, onde a liberdade dos escravos não viabilizou, sozinha, sua subsistência, haja vista que os mesmos não podiam consumir face a ausência de dinheiro para a compra, ou seja, em toda medida, não circulou a moeda, havendo um arrefecimento da economia.

De sorte que, em vez de manter os padrões salariais em termos dignos, independentemente do quantum de empregados, descontando da sua cota lucrativa a ampliação daqueles, o poder punitivo, visando aumentar gradientemente seus lucros, deseja não gastar muito com o pagamento salarial, mas, também, vender cada vez mais seus produtos, o que se inviabilizaria diante da eventual e sempre possível disparada do excedente de mão de obra em direção ao mercado de trabalho.

Por isto, é imprescindível ao capitalista/poder punitivo, controlar o mercado da mão de obra, mantendo-o em um equilíbrio tal que compatibilize salários baixos com poder aquisitivo!

Com efeito, o poder punitivo, mediante a pena, procura harmonizar o baixo custo salarial com o empregado e a capacidade aquisitiva deste.

De sorte que, o mercado, o capitalista, o empregador e o poder punitivo, precisam de mão de obra, empregados e cidadãos dóceis que aceitem se submeter, em sua maioria, a salários indignos, mas, sobretudo, de consumidores ativos. ${ }^{19}$

Ora, a reincidência da criminalização pelo poder punitivo em seu segundo apontar de dedos - ou mesmo no primeiro, mediante a teoria do desvio secundário ${ }^{20}$-, visa a evitar que o criminalizado, amargurado - na linguagem corrente da criminologia, "não docilizado" -, retorne ao mercado de trabalho incapaz - não só tecnicamente, senão, também -, de aceitar as condições sub-humanas em que dedica seu labor. Mesmo assim, para ele, há sempre a válvula de escape cujo mostrador avisa-o de que a inaceitação de referidas condições o devolverá ao mercado carcerário, sempre disposto a - por escambo -, regurgitar um substituto para sua

\footnotetext{
${ }^{18}$ Hoje, a China é um exemplo evidente disto.

${ }^{19}$ Sobre uma das conotações dos "consumidores ativos", veja ZAFFARONI, Eugenio Raúl; BATISTA, Nilo; ALAGIA, Alejandro; SLOKAR, Alejandro. Direito..., pp. 484-486.

${ }^{20}$ Quanto a ela, veja ZAFFARONI, Eugenio Raúl; BATISTA, Nilo; ALAGIA, Alejandro; SLOKAR, Alejandro. Direito.., p. 46.
} 
função, naquela lógica aritmética, e sempre útil psicologicamente ao poder punitivo, em que seis equivale à meia dúzia.

A socialização ${ }^{21}$ - termo cujo uso admito fazer aqui certa concessão em lugar de estigmatização, que entendo mais conveniente e coerente com criminalização e criminalizado -, que o poder punitivo objetiva com a pena, nada mais é, portanto, que a reciclagem do material inservível, por enquanto, ao mercado de trabalho, cuja reindustralização, sempre no maquinário obsoleto da prisão, tende a, mediante produção prêt-à-porter, armazenar no fundo de comércio carcerário, em prateleira exposta a pouca luz, calor e muita umidade, possíveis empregados domesticados, com prazo de validade vencível a curto prazo, senão pasteurizados (prevenção geral negativa).

$\mathrm{Ou}$, como preferem os americanos, campeões do encarceramento fordista, é preciso etiquetar neles, com letra graúda, o best before, para que não haja perda inútil do investimento, ou melhor, custo.

A criminalização da mentira veiculada em currículo serviria, portanto, como queiram, não de ressocialização ou de socialização, senão, de readestramento, de reeducação com o uso de palmatória, daqueles que já demonstraram representar um perigo - dificilmente delével -, para o domínio discursivo do poder punitivo, sendo encarcerados para que aprendam a restringir-se à sua alegada insignificância, ou, quando muito - para aqueles que têm a sorte de se (re)introduzirem no mercado laborativo -, a uma significância conveniente às necessidades do mercado de mão de obra onde, obviamente, terão direitos - estão pensando o quê, que eles não os teriam $?^{22}$-, quais sendo, aqueles trazidos da carceragem, é dizer, a carteira assinada (FAC - Farisaísmo facilmente Acessível do Criminoso) e a carta de recomendação (alvará de soltura). ${ }^{23}$

Quase que esgotados os argumentos preventivistas, resta o da prevenção especial negativa, ou seja, o da neutralização.

Referida neutralização, buscada pelo poder punitivo com a pena, representa sua tentativa de eliminar qualquer perigo, ameaça ou lesão advindos dos inempregáveis ${ }^{24}$,

\footnotetext{
${ }^{21}$ Como HASSEMER, prefiro socialização ao vocábulo ressocialização, porquanto, pelo lógica do poder punitivo, quer parecer que o criminalizado que precisa de uma socialização, não teria sido, adequadamente, socializado. Ou seja, ressocialização pressupõe socialização defeituosa, o que não me parece ser a lógica do poder punitivo. Parece, ao contrário, que ele sequer foi socializado, adequadamente. Sobre o que ele pensa, veja HASSEMER, Winfried. Introdução..., p. 374, nota 693.

22 Obviamente, estou sendo irônico sem desejar ser sádico.

${ }^{23}$ Em toda medida, este é um trocadilho que não pretende ser engraçado.

${ }^{24}$ O vocábulo não é meu, tendo sido tomado de empréstimo de WACQUANT, Loïc. As prisões da miséria. Rio de Janeiro: Jorge Zahar, 2001, p. 143, e BATISTA, Nilo. Entrevista à Unirio, por TUTTMAN, Malvina;
} 
despejando-os nas instituições de sequestro - prisões e hospitais psiquiátricos, v. g. -, capacitadas a ali mantê-los até a convocação conveniente daquele mesmo poder punitivo que, deles necessitando, não se furtará, mediante as agências que com ele se comunicam executivas (polícias), judiciário e legislativo -, de convocá-los a abastecer suas frentes de trabalho, todas voltadas aos seus fins.

Ou alguém duvida que um empregável, com qualificação e competência raras, mentindo em seu currículo, embora desnecessite disto, e, sendo preso, não será logo solto caso o mercado, e o capitalista, dele precisem para espraiar seus lucros ${ }^{25}$ Infelizmente, os incapacitados não têm a mesma sorte, visto que sua fungibilidade serve de moeda de troca. Moeda esta que tem uma coroa em cada um dos dois lados, e nenhuma cara! ${ }^{26}$

Neutralizado in loco, ao ser proscrito do mercado de trabalho e, depois, neutralizado externamente, ao ser encarcerado, e por fim, neutralizado por pasteurização, quando, após sua reciclagem, passa ele a aceitar, dócil e utilmente, condições indignas de trabalho, assumirá quem mentir no currículo a condição não de ser humano que busca sobreviver mediante argumentos mendazes que não fazem mal suficiente a ponto de atrair a privação da liberdade, mas de objeto de outra falácia - esta propalada pelo poder punitivo -, qual sendo, a de que a pena é uma mentira que não tem perna curta.

A pena seria nada mais que uma aposentadoria por invalidez, mediante neutralização (prevenção especial negativa), sem direito à remuneração.

Inegável é, portanto, o mister de rescindir, em termos, o contrato social entabulado com o Estado na parte em que ele afirma possuir o direito de punir - quando na verdade, ele se arrogou o poder de punir -, porquanto consignado em cláusula leonina, transmissível ao controle dos cidadãos que devem, todos, ser considerados consumidores ativos, e não meros empregados, de produtos que precisam possuir não só um conteúdo digno, senão, também, informações verídicas em seu rótulo.

SCHREIBER, Simone. In Nilo Batista: a luta pelo Direito. Rio de Janeiro: Chronos, publicação da Unirio, 2007, ano 2, n. 4, p. 138.

${ }^{25}$ Mutatis mutandis, um pouco do que eu disse pode ser encontrado em GROSNER, Marina Quezado. A seletividade do sistema penal na jurisprudência do Superior Tribunal de Justiça: o trancamento da criminalização secundária por decisões em habeas corpus. São Paulo: IBCCrim, 2008, n. 45, passim.

${ }^{26}$ Preferi "cara" a "face" ou "rosto", para guardar coerência com a nomenclatura coloquial "cara ou coroa". Sobre a ausência de face do inimigo no Direito Penal, veja ZAFFARONI, Eugenio Raúl. O inimigo no Direito Penal. In coleção pensamento criminológico, n. 14. Rio de Janeiro: Revan/ICC, 2007, pp. 19 e 104: "É inevitável que o Estado proceda dessa maneira, porque por trás da máscara acredita encontrar um inimigo, retiralhe a máscara e com isso, automaticamente, elimina-o do seu teatro (ou de seu carnaval, conforme o caso). ...Aquele que pretende saber quem é o inimigo com um simples olhar para o mundo minimiza ou nem sequer apercebe-se do risco da arbitrariedade política: o inimigo é quem é inimigo. Dessa perspectiva, pode-se afirmar que qualquer pretensão do poder político de impor a etiqueta a quem não é inimigo seria imediatamente desqualificada ao verificar-se empiricamente que o rótulo é falso." 
Então, embora mentir, na situação do projeto, ainda não seja uma conduta criminalizada, e oxalá nunca o seja, espero ter evidenciado que os efeitos manifestos da pena possuem uma eloquência funcional, retributiva e preventiva, que não passa de um engodo que ao longo de cinco séculos, em nosso país, tem conseguido acobertar sua verdadeira utilidade, qual sendo, a de controlar o excedente de mão de obra e, assim, estabilizar, quando não ampliar, os lucros do capitalista mediante a disposição nas gôndolas mercadistas dos invisíveis, embora eventualmente úteis, associais, acessíveis de acordo com a conveniência e a necessidade da economia.

Além de tudo isto, dogmaticamente, parece haver uma desarrazoabilidade e uma desproporção entre a sanção da criminalização prevista no artigo 298, do Código Penal e aquela pretendida com o famigerado projeto de lei, porquanto aquela comina a pena de reclusão, de um a cinco anos, enquanto esta, detenção, de dois meses a dois anos.

Pois bem. A desarrazoabilidade advém do fato de que, como no artigo 298, do Código Penal, aqui também se trata de documento particular (currículo), bem como de mentira veiculada no referido instrumento. Sendo assim, e não que se esteja legitimando a criminalização imposta no artigo 298, do Código Penal, diante deste, certamente é prescindível nova criminalização para fato já criminalizado, sob pena de bis in idem típico, insegurança subsuntiva e tratamento desigual para conjunturas materialmente iguais.

Já a desproporção, e, aqui, também não se está defendendo a legitimidade do artigo 298, do Código Penal, tampouco sua sanção - embora se esteja levando em conta que “...já que é impossível demonstrar a racionalidade da pena, as agências jurídicas devem, pelo menos, demonstrar que o custo em direitos da suspensão do conflito mantém uma proporcionalidade mínima com o grau da lesão que tenha provocado. ... o direito penal deve escolher entre irracionalidades, deixando passar a de menor conteúdo ${ }^{27}$-, descortina-se quando se compara a pena cominada naquele artigo e a prevista no projeto de lei que, embora mais eufemista, seja na quantidade, seja na modalidade do regime, representa uma disparidade para situações iguais.

Obviamente que, requente-se, qualquer redução da sanção já será bem vinda, ad instar da afirmação de ZAFFARONI, BATISTA, ALAGIA e SLOKAR de que "a hipótese inversa, na qual surge um irracional privilégio em certas cominações penais, no sentido de minimizar uma ofensa completamente equiparável a outra mais gravemente apenada, também se faz presente nas leis penais. O médico que, no exercício de sua profissão, emite um falso atestado

${ }^{27}$ ZAFFARONI, Eugenio Raúl; BATISTA, Nilo; ALAGIA, Alejandro; SLOKAR, Alejandro. Direito..., p. 230. 
submete-se à pena de detenção de um mês a um ano (art. 302, CP), enquanto que a falsidade ideológica de documento particular é punida com reclusão de um a três anos (art. 299, CP); cabe entender que todo atestado falso emitido privadamente por qualquer profissional nos limites de sua competência não pode acarretar-lhe pena superior à do médico (analogia in bonam partem corrigindo a irracionalidade do privilégio)., 28

No mais, parece que há um equívoco no escopo do projeto, porquanto ele se atém à falsidade material, olvidando a ideológica, que tem se mostrado a mais recorrente quando da confecção dos curricula.

I. e., se o objetivo - malfadado, evidentemente -, era evitar a veiculação de mentira, deveria a tentativa projetada legalmente de criminalização se reportar à falsificação ideológica, e não à material.

Como é de sabença cediça, na natureza, todos que mentem o fazem para sobreviver, seja para se proteger, seja para se alimentar. Esse mimetismo, portanto, advém de estruturas lógico-objetivas, e, por isso, deve ser respeitado pelo poder punitivo, sob pena de irrazoabilidade. Quando o candidato mente em seu currículo, nada mais faz que obedecer a uma estrutura valorativo-real, qual sendo, a da necessidade de sobrevivência, veiculada na tentativa de reequacionar a vulnerabilidade que foi burilada no currículo da sua vida. Desrespeitar essa lógica é irrelevar a natureza das coisas.

Para alguém que tem pernas tão curtas, as gulozeimas de Chapeuzinho chegaram longe demais. Será que o lobo das estepes de ZAFFARONI que a estará esperando ${ }^{29}$, conseguirá convencê-la de que é a vovozinha? Ou será que esse seu mendaz emprego experimental ensejará sua demissão, ou melhor, sua morte civil-trabalhista pelo lenhador?

\section{Referências}

ZAFFARONI, Eugenio Raúl; BATISTA, Nilo; ALAGIA, Alejandro; SLOKAR, Alejandro. Direito Penal brasileiro: teoria geral do Direito Penal, v. I. Rio de Janeiro: Revan, 2003.

\footnotetext{
${ }^{28}$ ZAFFARONI, Eugenio Raúl; BATISTA, Nilo; ALAGIA, Alejandro; SLOKAR, Alejandro. Direito..., pp. 231-232.

${ }^{29}$ Refiro-me, aqui, às estruturas lógico-objetivas que ZAFFARONI utiliza como instrumento de contenção ao poder punitivo em sua obra ZAFFARONI, Eugenio Raúl. Em busca das penas perdidas: a perda de legitimidade do sistema penal. 5. ed. Rio de Janeiro: Revan, 2001, passim.
} 
MELOSSI, Dario; PAVARINI, Massimo. Cárcere e fábrica: as origens do sistema penitenciário (séculos XVI - XIX). In coleção pensamento criminológico, n. 11. Rio de Janeiro: Revan/ICC, 2006.

COSTA, Jurandir Freire. Ordem médica e norma familiar. 5. ed. Rio de Janeiro: Graal, 2004.

BATISTA, Nilo. Punidos e mal pagos: violência, justiça, segurança pública e direitos humanos no Brasil de hoje. Rio de Janeiro: Revan, 1990.

RASPE, Rudolf Erich; BÜRGER, Gottfried August. As aventuras do barão de Münchhausen. São Paulo: Círculo do Livro, sem data.

RUSCHE, Georg; KIRCHHEIMER, Otto. Punição e estrutura social. In coleção pensamento criminológico, n. 3. 2. ed., Rio de Janeiro: Revan/ICC, 2004.

HASSEMER, Winfried. Introdução aos fundamentos do Direito Penal. Porto Alegre: SAFE, 2005 .

WACQUANT, Loïc. As prisões da miséria. Rio de Janeiro: Jorge Zahar, 2001, p. 143,

BATISTA, Nilo. Entrevista à Unirio, por TUTTMAN, Malvina; SCHREIBER, Simone. In Nilo Batista: a luta pelo Direito. Rio de Janeiro: Chronos, publicação da Unirio, 2007, ano 2, n. 4.

GROSNER, Marina Quezado. A seletividade do sistema penal na jurisprudência do Superior Tribunal de Justiça: o trancamento da criminalização secundária por decisões em habeas corpus. São Paulo: IBCCrim, 2008, n. 45.

ZAFFARONI, Eugenio Raúl. O inimigo no Direito Penal. In coleção pensamento criminológico, n. 14. Rio de Janeiro: Revan/ICC, 2007.

ZAFFARONI, Eugenio Raúl. Em busca das penas perdidas: a perda de legitimidade do sistema penal. 5. ed. Rio de Janeiro: Revan, 2001. 